\title{
Marine carbonate system evolution during the EPOCA Arctic pelagic ecosystem experiment in the context of simulated Arctic ocean acidification
}

R. G. J. Bellerby ${ }^{1,2,3,4}$, A. Silyakova ${ }^{2,3}$, G. Nondal ${ }^{1}$, D. Slagstad ${ }^{5}$, J. Czerny $^{6}$, T. de Lange ${ }^{4,3}$, and A. Ludwig ${ }^{6}$

${ }^{1}$ Norwegian Institute for Water Research, Thormøhlensgate 53 D, 5006 Bergen, Norway

${ }^{2}$ Uni Research, Allégaten 55, 5007 Bergen, Norway

${ }^{3}$ Bjerknes Centre for Climate Research, Allégaten 55, 5007 Bergen, Norway

${ }^{4}$ Geophysical Institute, University of Bergen, Allégaten 70, 5007 Bergen, Norway

${ }^{5}$ SINTEF Fisheries and Aquaculture, 7465 Trondheim, Norway

${ }^{6}$ Leibniz Institute of Marine Sciences (IFM-GEOMAR), Düsternbrooker Weg 20, 24105 Kiel, Germany

Received: 7 September 2012 - Accepted: 25 September 2012 - Published: 5 November 2012 Correspondence to: R. G. J. Bellerby (richard.bellerby@ niva.no)

Published by Copernicus Publications on behalf of the European Geosciences Union.
Marine carbonate system evolution

R. G. J. Bellerby et al.

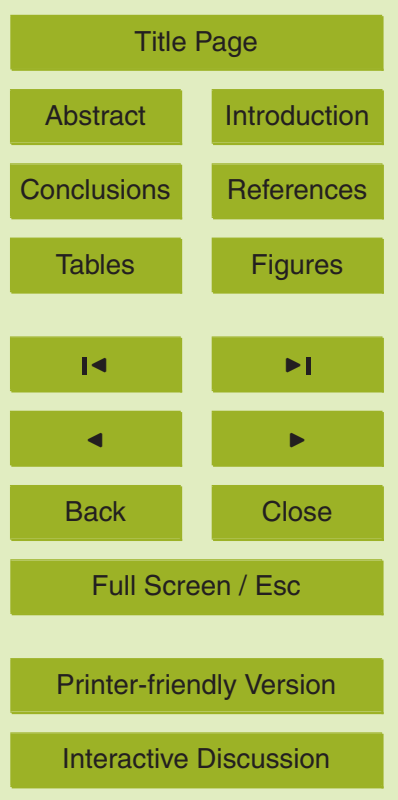

15541 


\section{Abstract}

A major, potential stressor of marine systems is the changing water chemistry following increasing seawater carbon dioxide concentration $\left(\mathrm{CO}_{2}\right)$, commonly termed ocean acidification. In order to understand how an Arctic pelagic ecosystem may respond 5 to future $\mathrm{CO}_{2}$, a deliberate ocean acidification and nutrient perturbation study was undertaken in an Arctic fjord. The initial setting and evolution of seawater carbonate chemistry were investigated. Additions of carbon dioxide resulted in a wide range of ocean acidification scenarios. This study documents the changes to the $\mathrm{CO}_{2}$ system throughout the study following net biological consumption and gas exchange with the phere. In light of the common practice of extrapolating results to cover regions away from experimental conditions, a modelling study was also performed to assess the representativeness, in the context of the simulated present and future carbonate system, of the experimental study region to both the near and wider Arctic region. The mesocosm experiment represented the range of simulated marine carbonate system for the coming century and beyond ( $\mathrm{CCO}_{2}$ to $\left.1420 \mu \mathrm{atm}\right)$ and thus extrapolations may be appropriate to ecosystems exhibiting similar levels of $\mathrm{CO}_{2}$ system drivers. However, as the regional ocean acidification was very heterogenous and did not follow changes in atmospheric $\mathrm{CO}_{2}$, care should be taken in extrapolating the mesocosm response to other regions based on atmospheric $\mathrm{CO}_{2}$ scenarios.

\section{Introduction}

Ocean observations of marine carbon dioxide concentrations (e.g. Sabine et al., 2004; Olsen et al., 2006, 2010; Vázquez-Rodríguez et al., 2009) have confirmed the changing ocean chemical state, in response to partial equilibration with increasing atmospheric $\mathrm{CO}_{2}$ concentrations. This build up of excess carbon results in a redistribution of dissolved carbon speciation and a lowering of pH (e.g. Zeebe and Wolf-Gladrow, 2001). This process has become known as ocean acidification (Caldeira and Wicket, 2003).
BGD

9, 15541-15565, 2012

Marine carbonate system evolution

R. G. J. Bellerby et al.

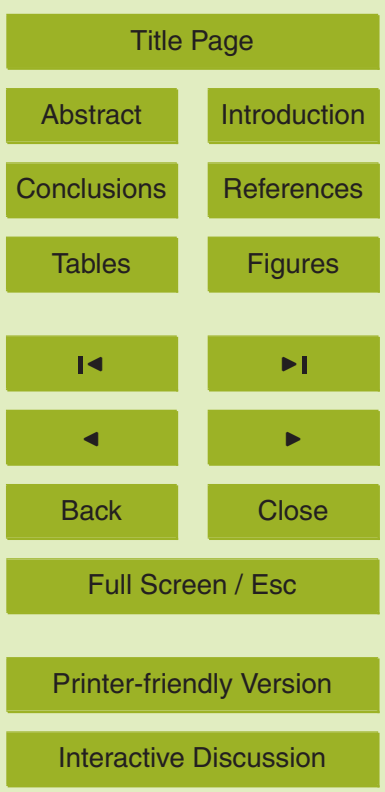

Interactive Discussion 
Model simulations point to an even greater rate of perturbation of the marine carbon cycle in the future with the earliest changes projected to occur in the Arctic (Orr et al., 2005; Bellerby et al.; 2005, Steinacher et al., 2009; Denman et al., 2011).

This oceanic uptake provides a great climate service by removing $\mathrm{CO}_{2}$ from the 5 atmosphere and thus reducing the greenhouse warming. The flipside of this oceanic uptake is that the shifting chemistry of the oceans may perturb physiological, ecological and biogeochemical processes, thereby changing the way that energy and elements are transported though marine systems. This may alter marine productivity and biodiversity, challenging both the ecological and economic sustainability of some marine 10 systems (Denman et al., 2011). One approach to understand ecological and biogeochemical responses to ocean acidification is to deliberately perturb marine ecosystems and organisms and then propagated through climate driven ocean models (e.g. Oschlies et al., 2007; Cheung et al., 2011). This form of information maybe then be used to inform ocean management frameworks under future climate change (Halpern et al., 15 2012).

This study explores the response of the marine carbonate system in an Arctic Fjord to deliberate carbonate system and nutrient perturbations and its subsequent evolution in net response to biological processes and air-sea gas exchange. Furthermore, to put the experiment in a broader pan-Arctic perspective, the experimental $\mathrm{CO}_{2}$ system sensitivity and variability are compared to regional scenarios of future ocean acidification around Svalbard from a regional coupled physical-ecosystem-carbon model.

\section{Methods}

\subsection{Experimental}

The experiment was performed in Kongsfjorden, Svalbard $78^{\circ} 56^{\prime} \mathrm{N} 11^{\circ} 54^{\prime} \mathrm{E}$, between 257 June and 7 July 2010. Nine floating mesocosm enclosures were deployed and filled quasi-simultaneously with in situ fjord water prior to additions of $\mathrm{CO}_{2}$ and nutrients

\section{BGD}

9, 15541-15565, 2012

Marine carbonate system evolution

R. G. J. Bellerby et al.

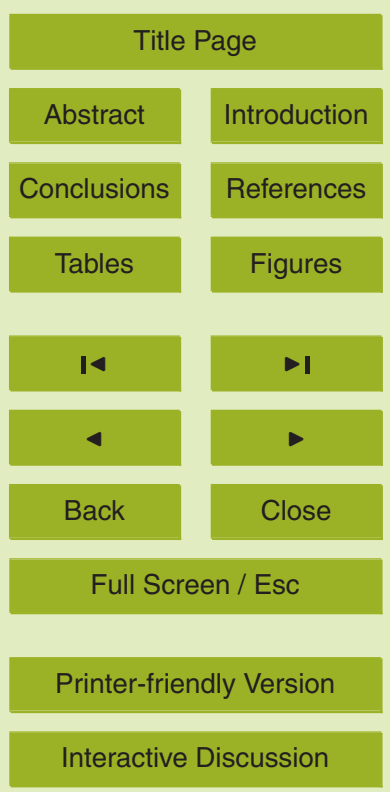


(Riebesell et al., 2012). Concurrent with sampling for other biogeochemical and biological variables, seawater samples for determining the carbon dioxide system were taken daily from the enclosures using an integrated water sampler (IWS, Hydrobios, Kiel) that took a $5 \mathrm{I}$ sample evenly drawn from a $12 \mathrm{~m}$ column in the enclosure. Samples for 5 total alkalinity $\left(A_{\mathrm{T}}\right)$ and total dissolved inorganic carbon $\left(C_{\mathrm{T}}\right)$ were drawn into $500 \mathrm{ml}$ borosilicate bottles. No filtering of sample prior to analysis was done due to the lack of significant calcifying plankton (Schulz et al., 2012; Brussard et al., 2012; Niehoff et al., 2012). $A_{\mathrm{T}}$ was measured using Gran potentiometric titration (Gran, 1952) on a VINDTA system (Mintrop et al., 2000) with a precision of $2 \mu \mathrm{mol} \mathrm{kg}{ }^{-1} . C_{\mathrm{T}}$ was determined using 10 coulometric titration (Johnson et al., 1987) with a precision of $\leq 2 \mu \mathrm{mol} \mathrm{kg}{ }^{-1}$. Measurements for both $C_{\mathrm{T}}$ and $A_{\mathrm{T}}$ were calibrated against certified reference material (CRM; Batch 101) (Dickson, 2010).

\subsection{Mesocosm $\mathrm{CO}_{2}$ system calculations}

The measured $C_{\mathrm{T}}$ and $A_{\mathrm{T}}$, with associated temperatures, salinity and dissolved nutrient data, were applied to the CO2SYS program (Lewis and Wallace, 1998) to calculate additional carbon dioxide system variables. To be consistent with Bellerby et al. (2008), we used the dissociation constants for carbonic acid of Dickson and Millero (1987), boric acid from Dickson (1990a), sulphuric acid following Dickson (1990b) and the $\mathrm{CO}_{2}$ solubility coefficients from Weiss (1974). Values are reported as in situ concentrations. Seawater $\mathrm{pH}$ is reported on the total hydrogen scale $\left(\mathrm{pH}_{\mathrm{T}}\right)$ and $\mathrm{pCO}_{2}$ in $\mu$ atm.

\subsection{Regional model description}

This study employed the SINTEF model (SINMOD), a coupled hydrodynamicecosystem model encompassed the Nordic Seas, the central Arctic Ocean and the Eurasian shelf (Fig. 1) (Slagstad and McClimans, 2005; Wassmann et al., 2006). The 25 hydrodynamic model is based on the primitive Navier-Stokes equations discretised on a z-grid (Slagstad and McClimans, 2005), and includes a sea-ice model similar to that of

\section{BGD}

9, 15541-15565, 2012

Marine carbonate system evolution

R. G. J. Bellerby et al.

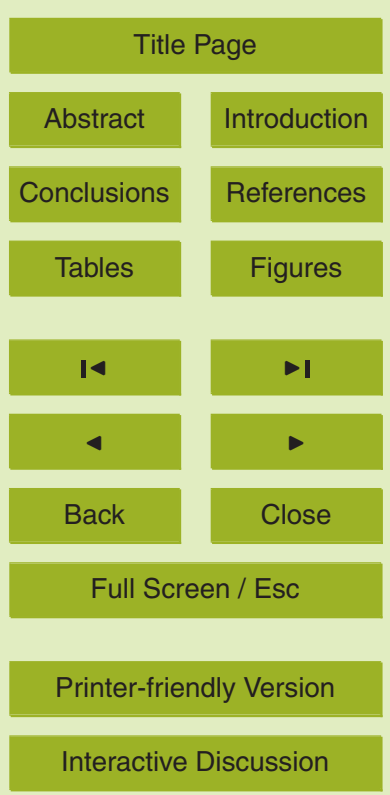


Hibler (1979). The sea ice model includes state variables for properties such as salinity, $A_{\mathrm{T}}$ and $C_{\mathrm{T}}$ allowing for these properties to be transported by ice drift and distributed during sea-ice melt. The structure of the ecological sub model is shown in Fig. 2. The basic model currency is nitrogen $\left(\mathrm{mmol} \mathrm{N} \mathrm{m}^{-3}\right.$ ), and the conversion to carbon is performed 5 using a $\mathrm{C}: \mathrm{N}$ ratio of 7.6 , based upon regional data from the Barents Sea (Reigstad et al., 2002). The state variables are: $C_{\mathrm{T}}, A_{\mathrm{T}}$, nitrate, ammonium, silicate, diatoms, autotrophic flagellates, bacteria, heterotrophic nanoflagellates, microzooplankton, fast sinking detritus, slow sinking detritus, dissolved organic carbon, bottom sediment and two groups of mesozooplankton, one representing the Atlantic species, Calanus finmarchicus and one, Calanus glacialis, representing the Arctic species.

\section{Set-up and boundary conditions}

The model employs a horizontal grid with a uniform resolution of $20 \mathrm{~km}$ and 25 vertical levels. Initial values of temperature and salinity were taken from the World Ocean Circulation Experiment Global Data Resource Version 3.0 (http://www.nodc.noaa.gov, 15 Lindstrom, 2001). SINMOD has open ocean boundaries to the Atlantic Ocean and the Bering Sea (Fig. 1). Water fluxes through these open boundaries were kept constant during the simulation; a flux of $0.8 \mathrm{~Sv}$ enters the model domain through the Bering Strait (Woodgate et al., 2010); on the Atlantic side the fluxes were derived from a large scale (50 km resolution) model covering the North Atlantic. A total of 8 tidal compo-

nents were imposed, specifying the various components at the open boundaries of the large-scale model. The model is also forced with freshwater fluxes from both river discharges and diffuse run-off from land. Freshwater run-off along the Norwegian coast and in the Barents Sea is based on data from a simulation with a hydrological model (see Dankers and Middelkoop, 2008 for more details). For Arctic Rivers flows, data

\section{BGD}

9, 15541-15565, 2012

Marine carbonate system evolution

R. G. J. Bellerby et al.

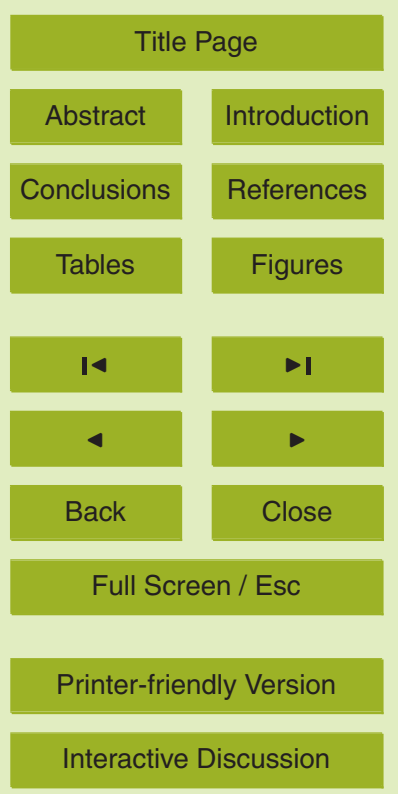

http://www.r-arcticnet.sr.unh.edu/v4.0/index.html. 
The climatic scenario runs use atmospheric forcing fields derived from a regional model system, configured to cover the model domain of SINMOD, run by the Max Planck Institute, (REMO; Keup-Thiel et al., 2006; Slagstad et al., 2011).

For marine biogeochemistry, monthly mean values of $C_{\mathrm{T}}, A_{\mathrm{T}}$, and nutrients from the 5 Bergen Climate Model (BCM) (Assmann et al., 2009), corrected using the CARINA database climatology (Tanhua et al., 2010) and the absolute delta change method (e.g. Hay et al., 2000), were used at the boundaries. From $C_{\mathrm{T}}$ and $A_{\mathrm{T}}$, with associated salinity and temperature, phosphate and silicate concentrations, the other $\mathrm{CO}_{2}$ system variables were determined following Dickson (2007) with the dissociation constants of 10 Mehrbach et al. (1973) modified by Leuker et al. (2000) on the total hydrogen scale. The representation of air-sea exchange of $\mathrm{CO}_{2}$ followed Wanninkhof (1992).

\section{Results and discussion}

The seawater for the experiment was isolated from the fjord on 2 June (t-5). The initial characterization of the $\mathrm{CO}_{2}$ system in the mesocosm and the fjord was performed on

$15 \mathrm{t}-3$ prior to the $\mathrm{CO}_{2}$ addition (Riebesell et al., 2012). The mesocosm values agreed to $\pm 1.2 \mu \mathrm{mol} \mathrm{kg}{ }^{-1}$, i.e. within the measurement precision, for both $C_{\mathrm{T}}$ and $A_{\mathrm{T}}$ (not shown). This confirmed that the closing of the bags isolated water of very similar biogeochemical properties in each mesocosm; a significant feat due to the typical small scale heterogeneity of the fjord (Svendsen et al., 2002). Following the final carbon dioxide perturbations on t4 (Schulz et al., 2012; Czerny et al., 2012a) it took a further four days for the $\mathrm{CO}_{2}$ system to settle down in the mesocosms due to exchange with "dead volume" in the base of the bags and thus, all changes to the $\mathrm{CO}_{2}$ fields were referenced to t-8.

$A_{\mathrm{T}}$ increased steadily in all the bags from $2242 \mu \mathrm{mol} \mathrm{kg}^{-1}$ on t8 to $2247 \mu \mathrm{mol} \mathrm{kg}^{-1}$ on t25 falling back to the original $2242 \mu \mathrm{mol} \mathrm{kg}^{-1}$ by $\mathrm{t} 27$. The increase was due to freshwa25 ter losses, following evaporation, and nutrient uptake (Silyakova et al., 2012). However, in the absence of significant numbers of calcifiers (Schulz et al., 2012; Brussard et al., 2012; Niehoff et al., 2012), there were no significant alkalinity changes following 15546

\section{BGD}

9, 15541-15565, 2012

Marine carbonate system evolution

R. G. J. Bellerby et al.

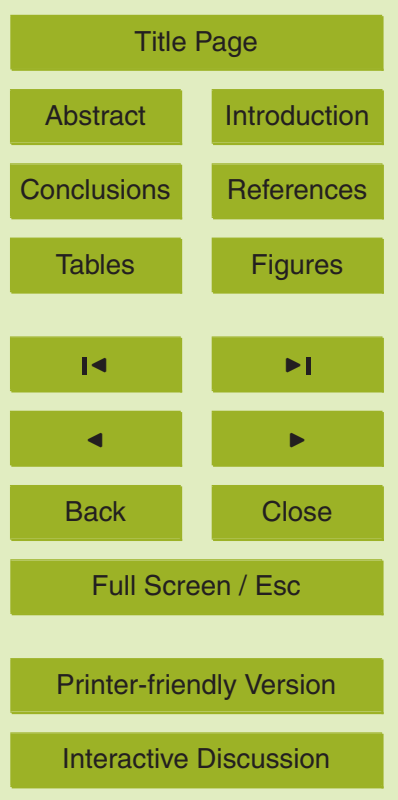


calcification. The effect of nutrient addition on t13 could not be seen in $A_{\mathrm{T}}$ as the addition was alkalinity neutral due to the concomitant addition of acid (Riebesell et al., 2012). As there were no other changes in other associated biogeochemical variables and salinity, it is likely that the drop in $A_{\mathrm{T}}$ on T27 was a calibration offset.

$5 \quad C_{\mathrm{T}}$ concentrations showed high variability between the mesocosms in response to the deliberate additions of $\mathrm{CO}_{2}$. From an original fjord value of about $1982 \mu \mathrm{mol} \mathrm{kg}^{-1}$, the perturbations spanned a range from 1982 to $2270 \mu \mathrm{mol} \mathrm{kg}^{-1}$. In the high $\mathrm{CO}_{2}$ scenarios, $C_{\mathrm{T}}$ drops rapidly and consistently throughout the experiment with net $C_{\mathrm{T}}$ changes between 52 and $63 \mu \mathrm{mol} \mathrm{kg}{ }^{-1}$. In the intermediate $\mathrm{CO}_{2}$ scenarios, $C_{\mathrm{T}}$ concen10 trations change much more slowly until about t23 when there is a much faster reduction. Total reductions in the intermediate scenario were between 54 and $58 \mu \mathrm{mol} \mathrm{kg}^{-1}$. In the low $\mathrm{CO}_{2}$ scenario mesocosms, $C_{\mathrm{T}}$ increases until t19 before exhibiting the fastest decline of all the scenarios towards the end of the experiment resulting in a net change of between 31 and $40 \mu \mathrm{mol} \mathrm{kg}^{-1}$.

The initial mesocosm $p \mathrm{CO}_{2}$ concentrations were chosen to represent a range of atmospheric values corresponding to anticipated carbon fossil fuel release scenarios. $\mathrm{pCO}_{2}$ showed very large inter- and intra-mesocosm variability, particularly in the high $\mathrm{CO}_{2}$ scenarios. This is due to the poor buffer capacity of the seawater that results in increasing sensitivity in $p \mathrm{CO}_{2}$ to even small changes in $C_{\mathrm{T}}$ and $A_{\mathrm{T}}$ that result from 20 both net ecosystem perturbations and from measurement sensitivity. The higher $\mathrm{CO}_{2}$ scenario mesocosms also exhibited the largest reductions in $\mathrm{pCO}_{2}$ enhanced by rapid gas exchange with the atmosphere.

Initial $\mathrm{pH}_{\mathrm{T}}$ levels ranged from 7.5 to 8.3 and, in all bags, increased through the experiments according to the relative amounts of $\mathrm{CO}_{2}$ exchange with the overlying atmo25 sphere and biological net carbon production. The high $\mathrm{CO}_{2}$ mesocosm exhibited the greatest $\mathrm{pH}$ changes.

The aragonite saturation state $\left(\Omega_{\mathrm{ar}}\right)$ had the highest values (2.6) in the control mesocosms. The seawater was under-saturated with respect to aragonite in the four highest $\mathrm{CO}_{2}$ mesocosms with the lowest $\Omega_{\mathrm{ar}}$ of the experiment being 0.5 . Seawater was

\section{BGD}

9, 15541-15565, 2012

Marine carbonate system evolution

R. G. J. Bellerby et al.

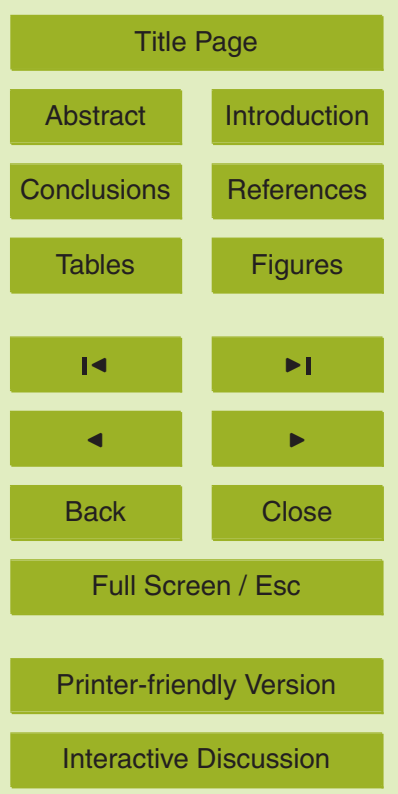


under-saturated with respect to aragonite for the entire experimental period under the highest $\mathrm{CO}_{2}$ scenario.

Carbonate system variability can be high in the surface ocean due to seasonal perturbations from biological $\mathrm{CO}_{2}$ uptake following photosynthesis and release through 5 respiration. The system also responds to the changes in solubility of $\mathrm{CO}_{2}$ that follow seasonal and episodic heating events. Furthermore, in the Arctic freshwater melt and river inputs can play a large role in determining the seasonal range and speciation of total inorganic carbon. Understanding the complex interplay of carbon cycle drivers requires a modeling approach to develop optimized simulations of future ocean acidifi10 cation.

One of the main purposes of this modelling exercise was to examine how the mesocosm carbonate system changes scaled in the context of broader regional ocean acidification changes simulated for the coming century. This study chose two approaches: the first was to study regions in juxtaposition with the Svalbard archipelago and; the 15 second to widen the view to encompass the waters of the northern Nordic Seas and the shelf regions and western Eurasian Basin of the Arctic Ocean. As the IPCC scenario SRESA1B was used in the model simulations, comparisons with the more wider ranging mesocosm experiment are constrained to those with atmospheric $\mathrm{CO}_{2}$ simulations between present and year 2100. These correspond most closely to mesocosm M1 and M4.

Most simulations of the future Arctic Ocean $\mathrm{CO}_{2}$ system have documented yearly average (Orr et al., 2005; Steinacher et al., 2009; Denman et al., 2011) or wintertime (Bellerby et al., 2005) ocean acidification. Of more relevance to biological systems and biogeochemical cycles is the seasonal cycle and overlying trends. For the regions around the Svalbard archipelago: the northern Barents Sea opening; the West Spitsbergen Current (WSC); and the northern Svalbard shelf (Fig. 3), the seasonal variability in the bi-weekly, mixed layer means for $\mathrm{pCO}_{2}, \mathrm{pH}_{\mathrm{T}}$ and $\Omega_{\mathrm{ar}}$ are shown in Fig. 6. The periods of study are the decades 2006-2015 and 2090-2099.

\section{BGD}

9, 15541-15565, 2012

Marine carbonate system evolution

R. G. J. Bellerby et al.

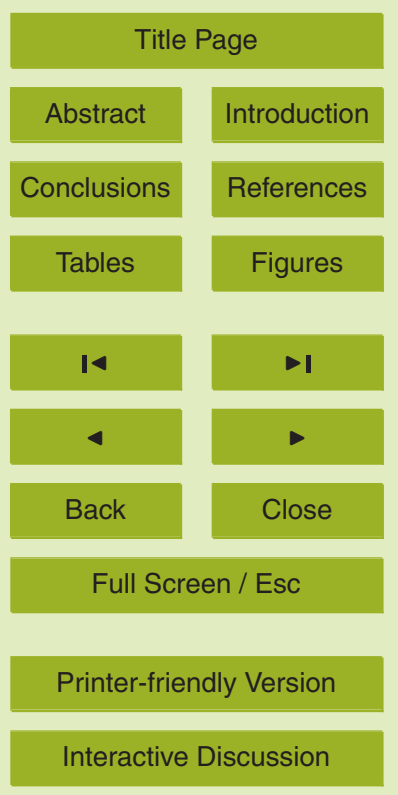

Interactive Discussion 
The modern model $p \mathrm{CO}_{2}$ cycle for the WSC is somewhat higher than the summertime values of the fjord and the control mesocosms. Further, due to the unseasonal forcing through a significant nutrient addition to the mesocosms, it is difficult to determine which stage of the year the mesocosms were simulating and thus allow a 5 complete comparison with rate of change of the spring bloom. The comparison does, however, enable a regional scaling of the experiment to anticipated changes in the coupled Arctic system and thus can inform on the limits to representation of oceanacidification-ecosystem responses founded from the mesocosm results.

This experiment pushed the envelope of $\mathrm{pCO}_{2}$ ranges beyond that which was studied 10 in the PeECE experiments (Bellerby at al., 2008). The large seasonal variability in the $\mathrm{CO}_{2}$ system exhibited in the models (Fig. 6) challenges the use of fixed $\mathrm{CO}_{2}$ system approaches. This study highlights the necessity to operate with mesocosms closely simulating natural variability the $\mathrm{CO}_{2}$ system following biological activity to allow more realistic seasonality. However, as the mesocosms were open to the contemporary at15 mosphere, and not one simulating the correct scenario atmospheric $p \mathrm{CO}_{2}$, as was done in the semi-closed systems in the PeECE study (Riebesell et al., 2008), air-sea exchange was a prominent driver of the net $\mathrm{CO}_{2}$ changes, especially at the lowest and highest scenarios (Czerny et al., 2012b). The rates of $\mathrm{CO}_{2}$ system change seen in the experiment can then only approximate the anticipated ocean acidification response expected from the initial $\mathrm{CO}_{2}$ levels. Accordingly, any results from the experiment should not be interpreted as corresponding to the representative year corresponding to a particular IPCC scenario. The experiment does allow for interpretation of results to the carbonate system chemistry. In summary, organisms, ecosystems and biogeochemistry are blind to operationally defined $\mathrm{CO}_{2}$ scenarios and thus it is not the atmospheric $\mathrm{CO}_{2}$ values that should guide interpretation of a response to $\mathrm{CO}_{2}$ but the absolute ocean acidification of the system at the phase of interest.

A larger sub-section of the full model domain was chosen to represent the variability in the marine carbonate system in the waters of the Nordic Seas and Arctic shelves north of Svalbard for decades at the beginning and the end of this century (Fig. 7).

\section{BGD}

9, 15541-15565, 2012

Marine carbonate system evolution

R. G. J. Bellerby et al.

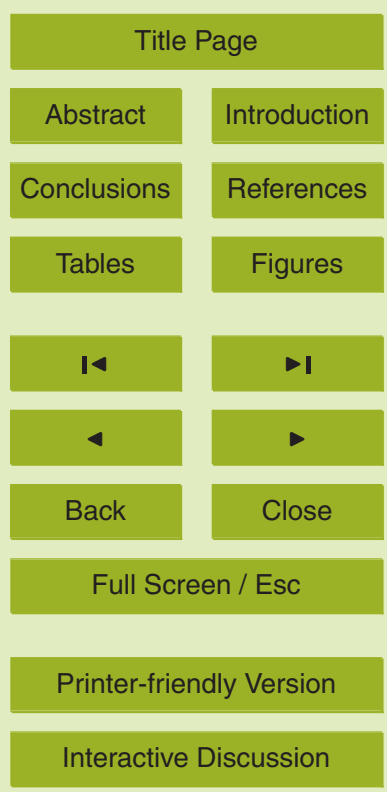


This region is driven by water masses and currents that incur a dominant control on the marine carbonate systems around Svalbard. These are predominantly the North Atlantic-, Norwegian Atlantic-, and West Spitsbergen Current chain, the East Greenland Current and the waters in the northern Barents Sea. The current chain can be 5 considered to be the "North Atlantic acidification highway" to the Arctic as it presently brings with it most of the anthropogenic carbon to the region (Olsen et al., 2006).

For the contemporary period 2006-2016, there is a $\mathrm{pCO}_{2}$ undersaturation for the entire region, with the highest values associated with the waters of the Iceland and Norwegian Seas. Concentrations increase towards the north until a rapid reduction in $10 \mathrm{pCO}_{2}$ is found at the Western Greenland Sea running north through the Fram Strait and rounding Svalbard towards the shelf north of the Barents Sea. Further north of this "front", $p \mathrm{CO}_{2}$ increases again to values similar to those in the northern Greenland Sea.

The regional, annually averaged, surface carbonate chemistry exhibits even greater heterogeneity in all $\mathrm{CO}_{2}$ system variables (Fig. 7) than the seasonal study local to the 15 Svalbard region (Fig. 6). The largest centennial changes are seen in the waters associated with the Arctic (Fig. 8) concurring with another independent model study of the region (Bellerby et al., 2005). There is a very clear demarcation where the largest changes in sea ice cover (not shown, Slagstad et al., 2011). It is this region that the greatest warming and freshening are simulated and these drive changes in ocean acidification in addition to those caused solely by increased $\mathrm{CO}_{2}$. Warming attenuates the drop in the saturation state and yet increases the $\mathrm{pH}$ reduction. Freshening causes a lowering of $A_{\mathrm{T}}$ and $C_{\mathrm{T}}$ that together result in a lowering of $\mathrm{pH}$ and of saturation state (e.g. Yamamoto-Kawai et al., 2009).

\section{Conclusions}

25 This study has documented the potential for significant ocean acidification perturbations in a future Arctic fjord environment. It reports on the the most northerly, large scale, mesocosm experiment to date and the most detailed to study an Arctic pelagic

\section{BGD}

9, 15541-15565, 2012

Marine carbonate system evolution

R. G. J. Bellerby et al.

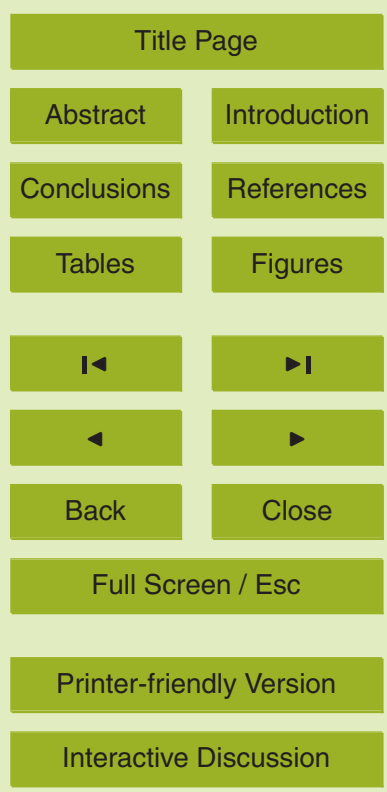


ecosystem. The model analysis is a first attempt to put mesocosm perturbations into a regional perspective. It recognizes the limitations of downscaling scenarios at the local scale with the course model resolution but it highlights the requirement for detailed local studies of ocean acidification relevant to individual organisms and ecosystems. The 5 modeling study highlights large heterogeneity in the regional and seasonal response of the marine carbonate system in the waters of the Arctic, with a focus on the waters around Svalbard. Climate change feedbacks on the $\mathrm{CO}_{2}$ system mainly through the very significant processes of warming and freshening. Incongruities with the absolute seasonal timing of the mesocosm with the model results in no way lessens the im10 portance in this experiment and its relevance for understanding ecosystem response. However, for inclusion of these results in management plans for the sustainability of this important region, caution should be taken in extrapolating the mesocosm results to represent thresholds or responses relevant to a particular time period. Whilst the results of organisms, ecosystems and biogeochemistry can be linked to absolute carbonate system properties, if information is required on the timing of these responses or the atmospheric $\mathrm{CO}_{2}$ concentrations under which these will occur, then a better understanding of the chemical setting is required. This highlights the need for more dedicated studies relevant to key species and biogeochemical provinces. For more realistic representations on future Arctic ecosystem responses it is required that multi-stressor experiments be performed. It is also apparent that under the same atmospheric forcing, the regional heterogeneity of future ocean acidification requires dedicated organismal and ecosystem investigations if informed management plans are to be developed.

Acknowledgements. This work was partially funded by the project "Marine Ecosystem Response to a Changing Climate" (MERCLIM No. 184860) financed by the program NORKLIMA 25 through the Norwegian Research Council and by the European Union Seventh Framework Program (FP7/2007-2013) through the projects "European Project on Ocean Acidification" (EPOCA No. 211384), "Marine Ecosystem Evolution in a Changing Environment" (MEECE No. 212085) and "Basin-scale Analysis, Synthesis and Integration" (EURO-BASIN No. 26493). We gratefully acknowledge the logistical support of Greenpeace International for its assistance 30 with the transport of the mesocosm. We also thank the captains and crews of M/V Esperanza 15551

\section{BGD}

9, 15541-15565, 2012

Marine carbonate system evolution

R. G. J. Bellerby et al.

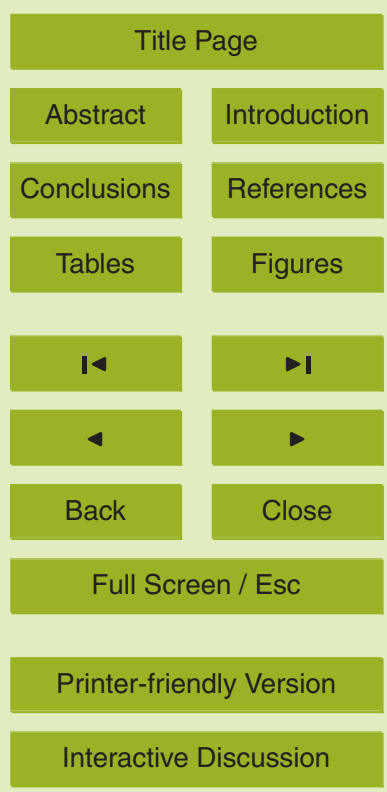

Interactive Discussion 
of Greenpeace and R/V Viking Explorer of the University Centre in Svalbard (UNIS) for assistance during mesocosm transport and during deployment and recovery in Kongsfjorden. We thank the staff of the French-German and Norwegian Arctic Research Bases at Ny-Ålesund, in particular Marcus Schumacher, for on-site logistical support.

\section{References}

Assmann, K. M., Bentsen, M., Segschneider, J., and Heinze, C.: An isopycnic ocean carbon cycle model, Geosci. Model Dev., 3, 143-167, doi:10.5194/gmd-3-143-2010, 2010.

Bellerby, R. G. J., Olsen A., Furevik T., and Anderson L. A.: Response of the surface ocean $\mathrm{CO}_{2}$ system in the Nordic Seas and North Atlantic to climate change, in: Climate Variability 10 in the Nordic Seas, edited by: Drange, H., Dokken, T. M., Furevik, T., Gerdes, R., and Berger, W., Geophysical Monograph Series, AGU, 189-198, 2005.

Bellerby, R. G. J., Schulz, K. G., Riebesell, U., Neill, C., Nondal, G., Heegaard, E., Johannessen, T., and Brown, K. R.: Marine ecosystem community carbon and nutrient uptake stoichiometry under varying ocean acidification during the PeECE III experiment, Biogeosciences, 5, 1517-1527, doi:10.5194/bg-5-1517-2008, 2008.

Caldeira, K. and Wickett, M. E.: Anthropogenic carbon and ocean pH, Nature 425, 365-365, 2003.

Cheung, W. W. L., Dunne, J., Sarmiento, J., and Pauly, D.: Integrating eco-physiology and plankton dynamics into projected changes in maximum fisheries catch potential under climate change in the northeast Atlantic, ICES J. Mar. Sci., 68, 1008-1018, 2011.

Czerny, J., Bellerby, R. G. J., Boxhammer, T., Engel, A., Krug, S. A., Ludwig, A., Nachtigall, K., Niehoff, B., Schulz, K. G., and Riebesell, U.: Element budgets in an arctic mesocosm $\mathrm{CO}_{2}$ perturbation study, Biogeosciences Discuss., in preparation, 2012a.

Czerny, J., Schulz K. G., Ludwig A., and Riebesell, U.: A simple method for air/sea gas exchange measurements in mesocosms, needed for carbon budget calculations, Biogeosciences Discuss., accepted, 2012b.

Dankers, R. and Middelkoop, H.: River discharge and freshwater runoff to the Barents Sea under present and future climate conditions, Climatic Change 87, 131-153, doi:10.1007/s10584-007-9349-x, 2008.

\section{BGD}

9, 15541-15565, 2012

Marine carbonate system evolution

R. G. J. Bellerby et al.

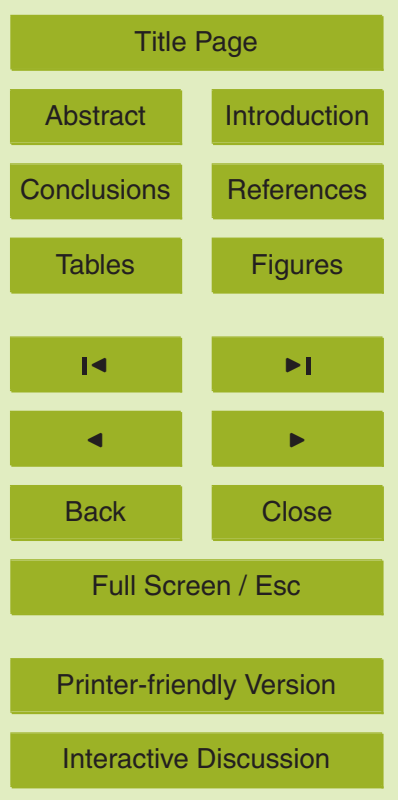


Denman, K., Christian, J. R., Steiner, N., Pörtner, H. O., and Nojiri, Y.: Potential impacts of future ocean acidification on marine ecosystems and fisheries: current knowledge and recommendations for future research, ICES J. Mar. Sci., 68, 1019-1029, 2011.

Dickson, A. G.: Standard potential of the reaction: $\mathrm{AgCl}(\mathrm{s})+1 / 2 \mathrm{H} 2(\mathrm{~g})=\mathrm{Ag}(\mathrm{s})+\mathrm{HCl}(\mathrm{aq})$, and the standard acidity constant of the ion HSO-4 in synthetic seawater from 273.15 to 318.15 K, J. Chem. Thermodyn., 22, 113-127, 1990a.

Dickson, A. G.: Thermodynamics of the dissociation of boric acid in synthetic sea water from 273.15 to $318.15 \mathrm{~K}$, Deep-Sea Res., 37, 755-766, $1990 \mathrm{~b}$.

Dickson, A. G.: Standards for Ocean Measurements, Oceanography, 23, 34-47, 2010.

Dickson, A. G. and Millero F. J.: A comparison of the equilibrium constants for the dissociation of carbonic acid in seawater media, Deep-Sea Res., 34, 1733-1743, 1987.

Gran, G.: Determination of the equivalence point in potentiometric titrations of seawater with hydrochloric acid, Oceanol. Acta, 5, 209-218, 1952.

Halpern, B. S., Longo, C., Hardy, McLeod, D. K. L., Samhouri, J. F., Katona, S. K., Kleisner, 15 K., Lester, S. E., O'Leary, J., Ranelletti, M., Rosenberg, A. A., Scarborough, C., Selig, E. R., Bes, B. D., Brumbaugh, D. R., Chapin III, F. S., Crowder, L. B., Daly, K. L., Doney, S. C., Elfes ,C., J. Fogarty, M., Gaines, S. D., Jacobsen, K., Karrer, L. B., Leslie, H. M., Neeley, E., Pauly, D., Polasky, S., Ris, B., Martin, K. St., Stone, G. S.,. Sumaila, U. R., and Zeller, D.: An index to assess the health and benefits of the global ocean, Nature, 488, 615-620, 2012.

Hay, L. E., Wilby, R. L., and Leavesley, G. H.: A comparison of delta change and downscaled GCM scenarios for three mountainous basins in the united states, J. Am. Water Resour. As., 36, 387-397, doi:10.1111/j.1752-1688.2000.tb04276.x, 2007.

Hibler III, W. D.: A dynamic thermodynamic sea ice model, J. Phys. Oceanogr., 9, 815-846, 1979.

Hunke, E. C. and Dukowicz, J. K.:, An elastic-viscous-plastic model for sea ice dynamics, J. Phys. Oceanogr., 27, 1849-1867, 1997.

Johnson, K. M., Sieburth, J. M., Williams, P. J., and Brandström, L.: Coulometric total carbon analysis for marine studies, automation and calibration, Mar. Chem., 21, 117-133, 1987.

Keup-Thiel, E., Gottel, H., and Jacob, D.: Regional climate simulations for the Barents Sea region, Boreal Environ. Res., 11, 329-339, 2006.

Lewis, E. and Wallace, D. W. R.: Program Developed for $\mathrm{CO}_{2}$ System Calculations, ORNL/CDIAC-105, Carbon Dioxide Information Analysis Center, Oak Ridge National Laboratory, US Department of Energy, Oak Ridge, Tennessee, 21pp., 1998.

\section{BGD}

9, 15541-15565, 2012

Marine carbonate system evolution

R. G. J. Bellerby et al.

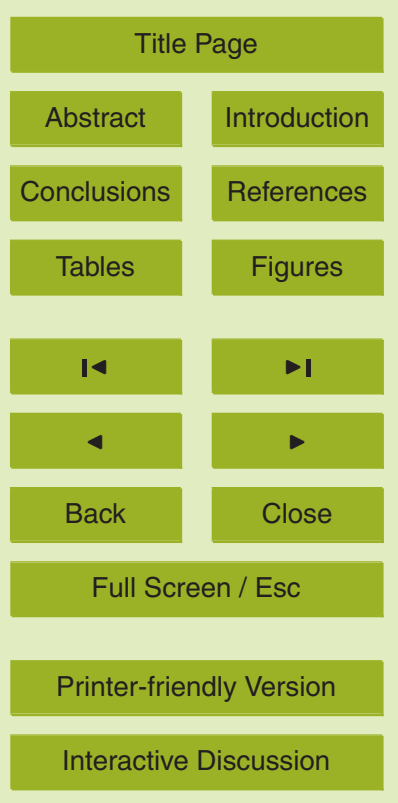


Lindstrom, E. J.: Developing the WOCE Global Data System, in: Ocean Circulation and Climate - Observing and Modelling the Global Ocean, edited by: Siedler, G., Church, J., and Gould, J., Academic Press, 181-190, 2001.

Lueker, T. J., Dickson, A. G., and Keeling, C. D.: Ocean $p \mathrm{CO}_{2}$ calculated from dissolved inorganic carbon, alkalinity, and equations for $\mathrm{K}-1$ and $\mathrm{K}-2$, in: validation based on laboratory measurements of $\mathrm{CO}_{2}$ in gas and seawater at equilibrium, Mar. Chem., 70, 105-119, 2000.

Mehrbach, C., Culberson, C. H., Hawley, J. E., and Pytkowic, R. M.: Measurement of Apparent Dissociation-Constants of Carbonic-Acid in Seawater at Atmospheric-Pressure, Limnol. Oceanogr., 18, 897-907, 1973.

10 Mintrop, L., Fernández-Pérez, F., González Dávila, M., Körtzinger, A., and Santana Casiano J. M.: Alkalinity determination by potentiometry- intercalibration using three different methods, Cienc. Mar., 26, 23-37, 2000.

Niehoff, B., Knüppel, N., Daase, M., Czerny, J., and Boxhammer, T.: Mesozooplankton community development at elevated $\mathrm{CO}_{2}$ concentrations: results from a mesocosm experiment in an Arctic fjord, Biogeosciences Discuss., 9, 11479-11515, doi:10.5194/bgd-9-11479-2012, 2012.

Oschlies, A., Schulz, K. G., Riebesell, U., and Schmittner, A.: Simulated 21st century's increase in oceanic suboxia by $\mathrm{CO}_{2}$-enhanced biotic carbon export, Global Biogeochem. Cy., 22, GB4008, doi:10.1029/2007GB003147, 2008.

Olsen, A., Omar, A. M., Bellerby, R. G. J., Johannessen, T., Ninnemann, U., Brown, K. R., Olsson, K. A, Olafsson, J., Nondal, G., Kivimäe, C., Kringstad, S., Neill, C., and Olafsdottir, S.: Magnitude and Origin of the Anthropogenic $\mathrm{CO}_{2}$ increase and ${ }^{13} \mathrm{C}$ Suess effect in the Nordic Seas Since 1981, Global Biogeochem. Cy., 20, GB3027, doi:10.1029/2005GB002669, 2006.

Olsen, A., Omar, A. M., Jeansson, E., Anderson, L. G., and Bellerby, R. G. J.: Nordic seas transit time distributions and anthropogenic $\mathrm{CO}_{2}$, J. Geophys. Res., 115, C05005, doi:10.1029/2009JC005488, 2010.

Orr, J. C., Fabry, V. J., Aumont, O., Bopp, L., Doney, S. C., Feely, R. A., Gnanadesikan, A., Gruber, N., Ishida, A., Joos, F., Key, R. M., Lindsay, K., Maier-Reimer, E., Matear, R., Monfray, P., Mouchet, A., Najjar, R. G., Plattner, G. K., Rodgers, K. B., Sabine, C. L., Sarmiento, J. L., Schlitzer, R., Slater, R. D., Totterdell, I. J., Weirig, M. F., Yamanaka, Y., and Yool, A.: Anthropogenic ocean acidification over the twenty-first century and its impact on calcifying organisms, Nature, 437, 681-686, doi:10.1038/nature04095, 2005.

BGD

9, 15541-15565, 2012

Marine carbonate system evolution

R. G. J. Bellerby et al.

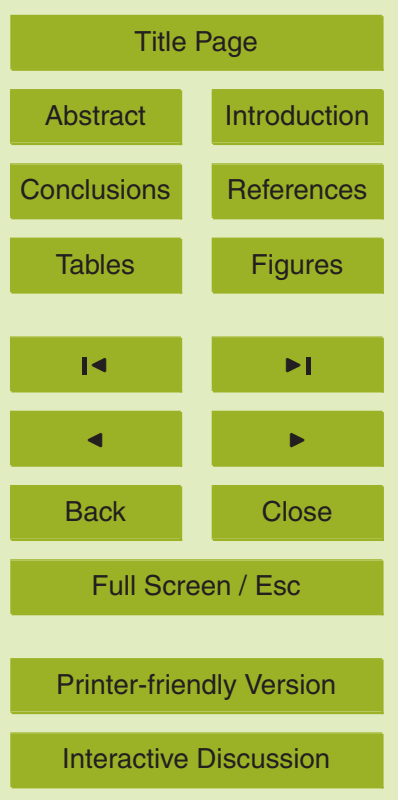

15554 
Riebesell, U., Schulz, K. G., Bellerby, R. G. J., Fritsche, P., Meyerhofer, M., Neill, C., Nondal, G., Oschlies, A., Wohlers, J., and Zollner, E.: Enhanced biological carbon consumption in a high $\mathrm{CO}_{2}$ ocean, Nature, 450, 545-548, 2007.

Riebesell, U., Bellerby, R. G. J., Grossart, H.-P., and Thingstad, F.: Mesocosm $\mathrm{CO}_{2}$ perturbation studies: from organism to community level, Biogeosciences, 5, 1157-1164, doi:10.5194/bg5-1157-2008, 2008.

Riebesell, U., Czerny, J., von Bröckel, K., Boxhammer, T., Büdenbender, J., Deckelnick, M., Fischer, M., Hoffmann, D., Krug, S. A., Lentz, U., Ludwig, A., Muche, R., and Schulz, K. G.: Technical Note: A mobile sea-going mesocosm system - new opportunities for ocean change research, Biogeosciences Discuss., 9, 12985-13017, doi:10.5194/bgd-9-12985-2012, 2012.

Reigstad, M., Wassmann, P., Riser, C. W., Oygarden, S., and Rey, F.: Variations in hydrography, nutrients and chlorophyll a in the marginal ice-zone and the central Barents Sea, J. Marine Syst., 38, 9-29, 2002.

Sabine, C. L., Feely, R. A., Gruber, N., Key, R. M., Lee, K., Bullister, J. L., Wanninkhof, R., 15 Wong, C. S., Wallace, D. W., Tilbrook, B., Millero, F. J., Peng, T. H., Kozyr, A., Ono, T., and Rios, A. F.: The oceanic sink for anthropogenic $\mathrm{CO}_{2}$, Science, 305, 367-371, 2004.

Schulz, K. G., Bellerby, R. G. J., Brussaard, C. P. D., Büdenbender, J., Czerny, J., Engel, A., Fischer, M., Koch-Klavsen, S., Krug, S. A., Lischka, S., Ludwig, A., Meyerhöfer, M., Nondal, G., Silyakova, A., Stuhr, A., and Riebesell, U.: Temporal biomass dynamics of an Arctic plankton bloom in response to increasing levels of atmospheric carbon dioxide, Biogeosciences Discuss., 9, 12543-12592, doi:10.5194/bgd-9-12543-2012, 2012.

Silyakova, A., Bellerby, R. G. J., Czerny, J., Schulz, K. G., Nondal, G., Tanaka, T., Engel, A., De Lange, T., and Riebesell, U.: Net community production and stoichiometry of nutrient consumption in a pelagic ecosystem of a northern high latitude fjord: mesocosm $\mathrm{CO}_{2}$ perturbation study, Biogeosciences Discuss., 9, 11705-11737, doi:10.5194/bgd-9-11705-2012, 2012.

Slagstad, D. and McClimans, T.: Modelling the ecosystem dynamics of the Barents Sea including the marginal ice zone: Physical and chemical oceanography, J. Marine Syst., 58, 1-18, 2005.

30 Slagstad, D., Ellingsen, I. H., and Wassmann, P.: Evaluating primary and secondary production in an Arctic Ocean void of summer sea ice: an experimental simulation approach, Prog. Oceanogr., 90, 117-131, doi:10.1016/j.pocean.2011.02.009, 2011.
BGD

9, 15541-15565, 2012

Marine carbonate system evolution

R. G. J. Bellerby et al.

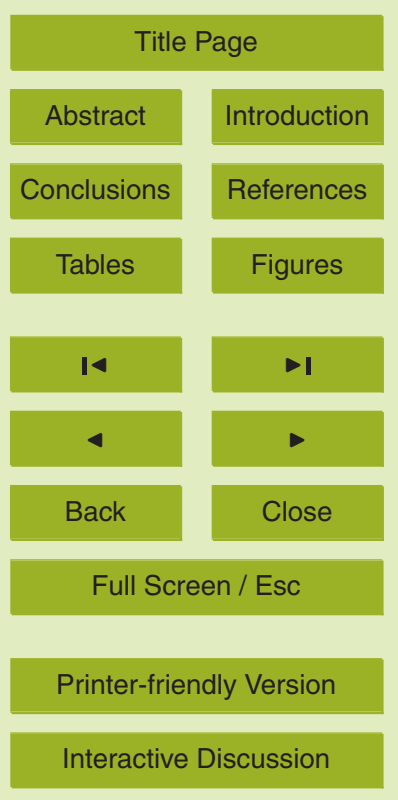


Steinacher, M., Joos, F., Frölicher, T. L., Plattner, G.-K., and Doney, S. C.: Imminent ocean acidification in the Arctic projected with the NCAR global coupled carbon cycle-climate model, Biogeosciences, 6, 515-533, doi:10.5194/bg-6-515-2009, 2009.

Steinhoff, T., Friedrich, T., Hartman, S. E., Oschlies, A., Wallace, D. W. R., and Körtzinger, 5 A.: Estimating mixed layer nitrate in the North Atlantic Ocean, Biogeosciences, 7, 795-807, doi:10.5194/bg-7-795-2010, 2010.

Svendsen, H., Beszczynska-Møller, A., Hagen, J. O., Lefauconnier, B., Tverberg, V., Gerland, S., Ørbøk, J. B., Bischof, K., Papucci, C., Zajaczkowski, M., Azzolini, R., Bruland, O., Wiencke, C., Winther, J. G., and Dallmann, W.: The physical environment of Kongsfjorden - Krossfjorden, an Arctic fjord system in Svalbard, Polar Res., 21, 133-166. doi:10.1111/j.1751-8369.2002.tb00072.x, 2002.

Tanhua, T., Steinfeldt, R., Key, R. M., Brown, P., Gruber, N., Wanninkhof, R., Perez, F., Körtzinger, A., Velo, A., Schuster, U., van Heuven, S., Bullister, J. L., Stendardo, I., Hoppema, M., Olsen, A., Kozyr, A., Pierrot, D., Schirnick, C., and Wallace, D. W. R.: Atlantic Ocean CARINA data: overview and salinity adjustments, Earth Syst. Sci. Data, 2, 17-34, doi:10.5194/essd-2-17-2010, 2010.

Vázquez-Rodríguez, M., Touratier, F., Lo Monaco, C., Waugh, D. W., Padin, X. A., Bellerby, R. G. J., Goyet, C., Metzl, N., Ríos, A. F., and Pérez, F. F.: Anthropogenic carbon distributions in the Atlantic Ocean: data-based estimates from the Arctic to the Antarctic, Biogeosciences, $20 \quad 6,439-451$, doi:10.5194/bg-6-439-2009, 2009.

Vörösmarty, C. J., Fekete, B., and Tucker, B. A.: River Discharge Database, Version 1.0 (RivDIS v1.0), Volumes 0 through 6, a contribution to IHP-V Theme 1, 1996.

Vörösmarty, C. J., Fekete, B., and Tucker, B. A.: River Discharge Database, Version 1.1 (RivDIS v1.0 supplement), available through the Institute for the Study of Earth, Oceans, and Space University of New Hampshire, Durham NH (USA), 1998.

Wanninkhof, R.: Relationship between wind-speed and gas-exchange over the ocean, J. Geophys. Res., 97, 7373-7382, 1992.

Wassmann, P., Reigstad, M., Haug, T., Rudels, B., Carroll, M. L., Hop, H., Gabrielsen, G. W., Falk-Petersen, S., Denisenko, S. G., Arashkevich, E., Slagstad, D., and Pavlova, O.: Food 30 webs and carbon flux in the Barents Sea, Prog. Oceanogr., 71, 232-287, 2006.

Weiss, R. F.: Carbon dioxide in water and seawater: the solubility of a non-ideal gas, Mar. Chem., 2, 203-215, 1974.

\section{BGD}

9, 15541-15565, 2012

Marine carbonate system evolution

R. G. J. Bellerby et al.

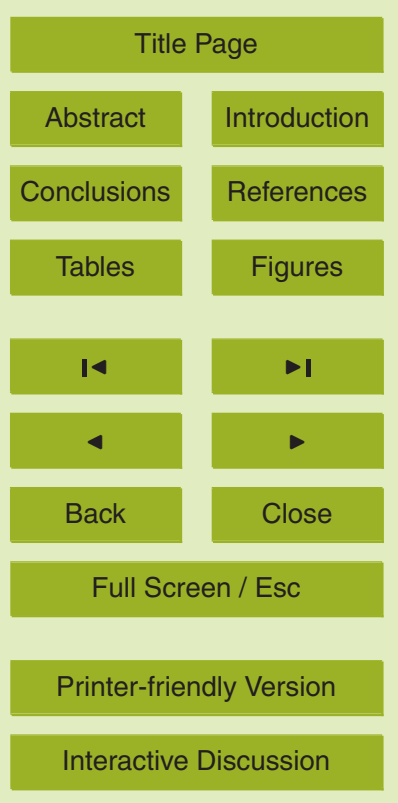


Woodgate, R. A., Weingartner, T., and Lindsay, R.: The 2007 Bering Strait oceanic heat flux and anomalous Arctic sea-ice retreat, Geophys. Res. Lett., 37, doi:10.1029/2009GL041621, 2010.

Yamamoto-Kawai, M., McLaughlin, F. A., Carmack, E. C., Nishino, S., and Shimada, K.: Arag5 onite undersaturation in the Arctic ocean: effect of ocean acidification and sea ice melt, Science, 326, 1098-1100, 2009.

Zeebe, R. E. and Wolf-Gladrow, D. A.: $\mathrm{CO}_{2}$ in Seawater: Equilibrium, Kinetics, Isotopes, Elsev. Oceanogr., 65, 346 pp., Amsterdam, 2001.

\section{BGD}

9, 15541-15565, 2012

\section{Marine carbonate system evolution}

R. G. J. Bellerby et al.

Title Page

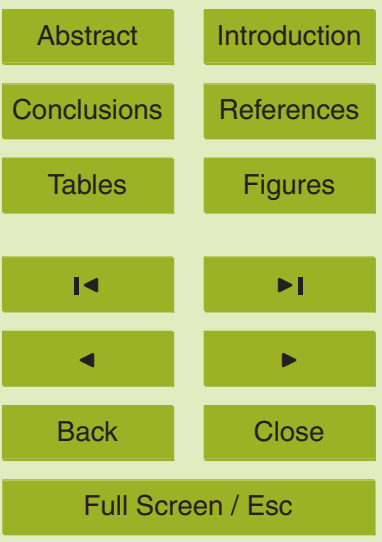

Printer-friendly Version

Interactive Discussion 


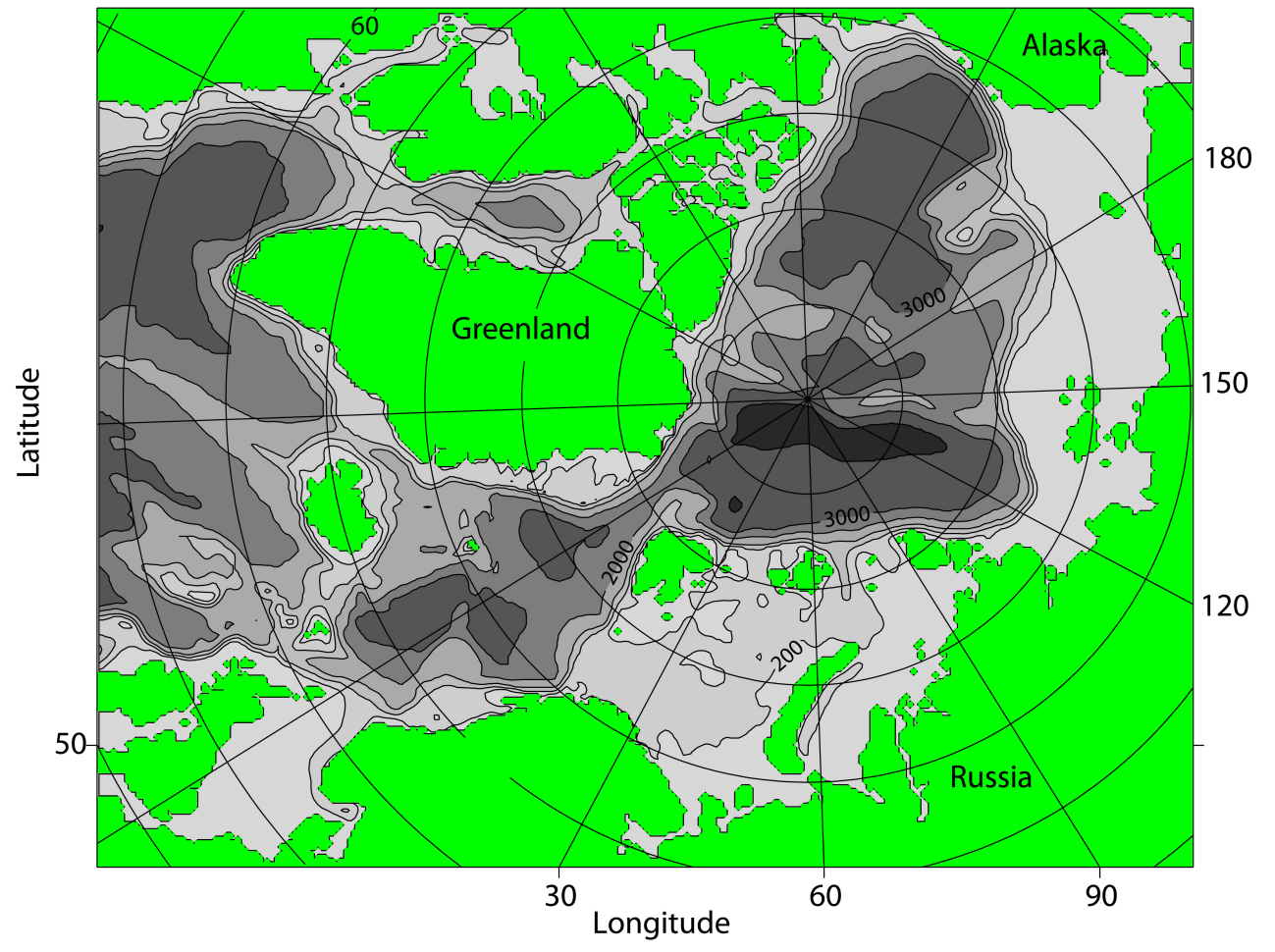

Fig. 1. Regional domain of the SINMOD model.

\section{BGD}

9, 15541-15565, 2012

\section{Marine carbonate system evolution}

R. G. J. Bellerby et al.

Title Page

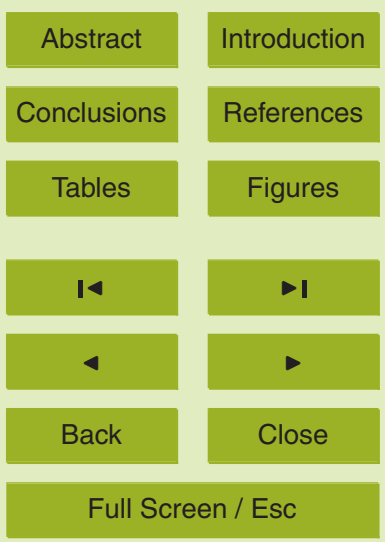

Printer-friendly Version

Interactive Discussion 


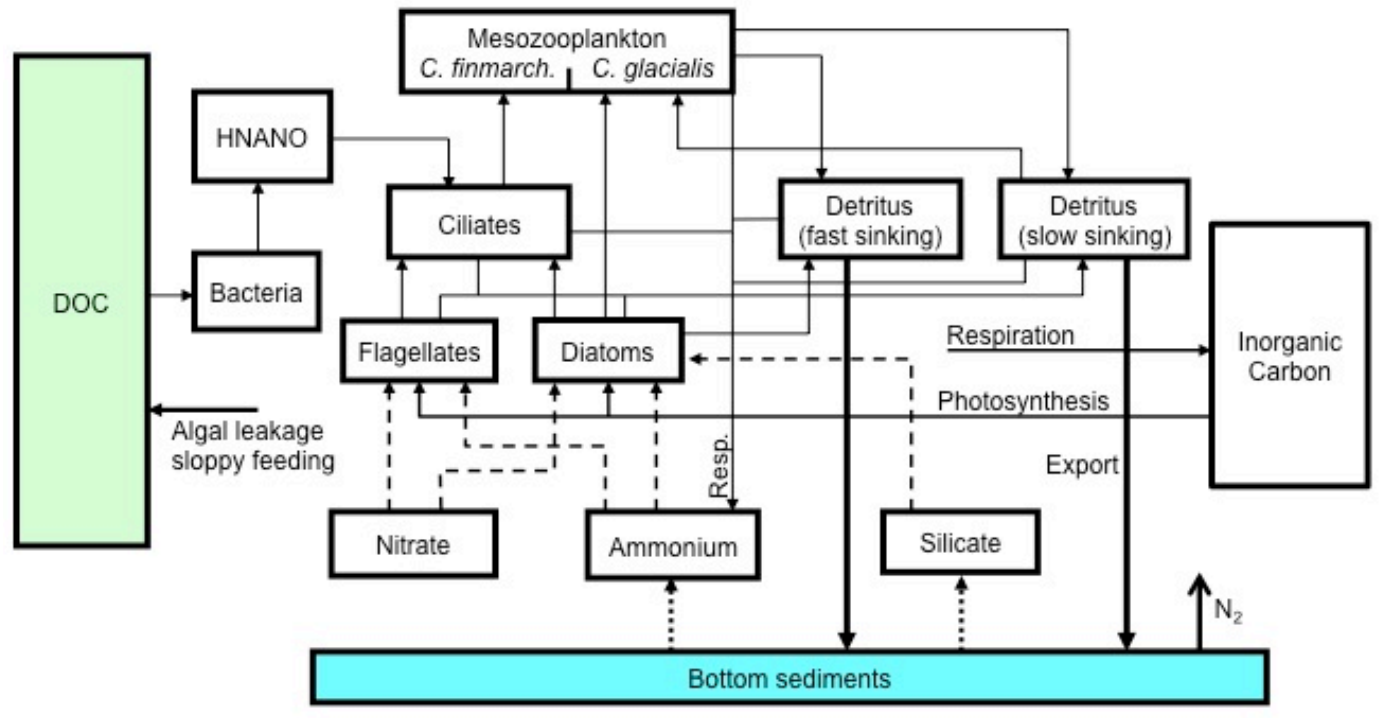

\section{BGD}

9, 15541-15565, 2012

\section{Marine carbonate system evolution}

R. G. J. Bellerby et al.

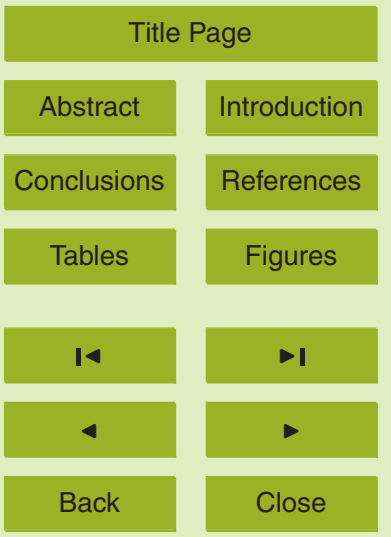

Fig. 2. Ecological and biogeochemical components of the SINMOD model and their interac-

Full Screen / Esc tions. 


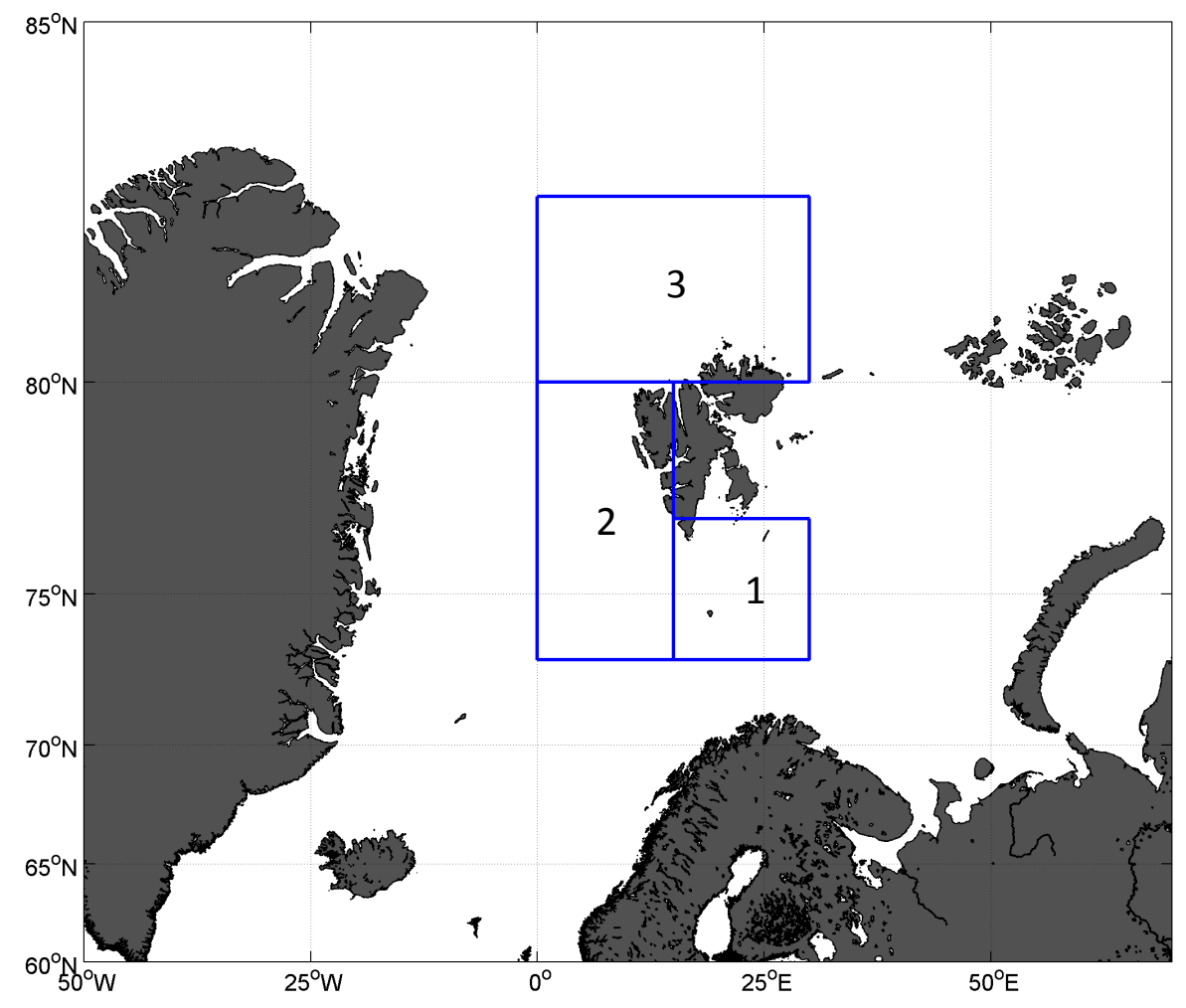

Fig. 3. Sub-regional domains for the seasonal modelling study. (1) Barents Sea Opening; (2) West Spitsbergen current and (3) Arctic Shelf.

\section{BGD}

9, 15541-15565, 2012

\section{Marine carbonate system evolution}

R. G. J. Bellerby et al.

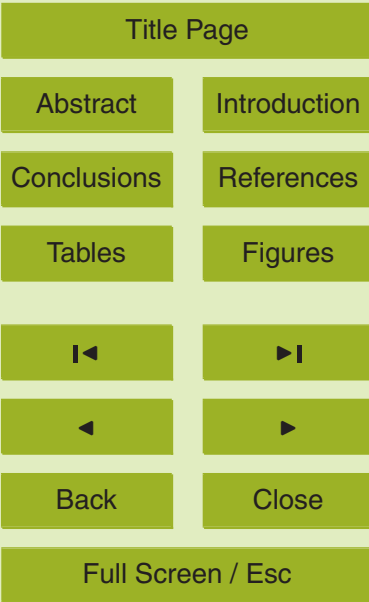

Printer-friendly Version

Interactive Discussion 

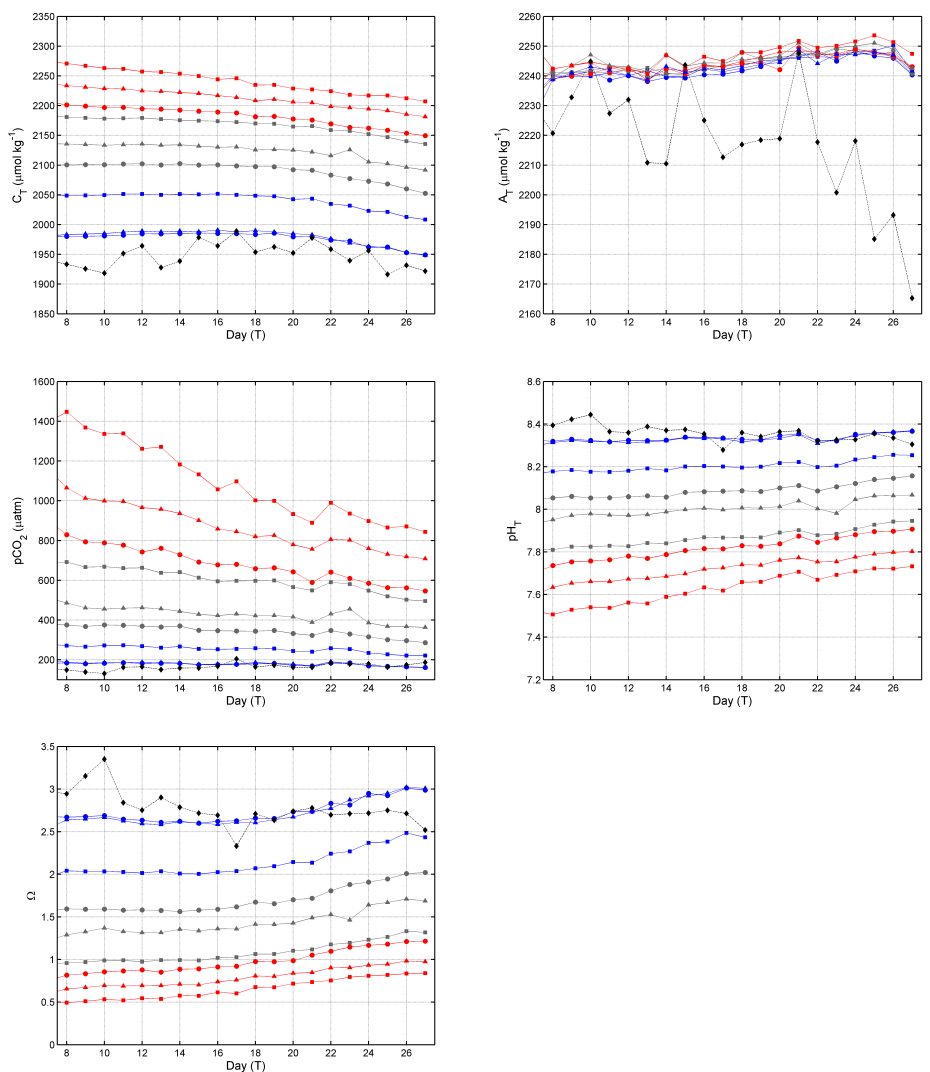

Fig. 4. Absolute values for the marine carbonate system variables. Measured values are (a) total inorganic carbon $\left(C_{\mathrm{T}}\right)$ and $(\mathbf{b})$ total alkalinity $\left(A_{\mathrm{T}}\right)$. Calculated values are (c) partial pressure of carbon dioxide $\left(p \mathrm{CO}_{2}\right)$, (d) $\mathrm{pH}_{\mathrm{T}}$ on the total hydrogen scale and (e) aragonite saturation state $\left(\Omega_{\mathrm{ar}}\right)$. Red symbols: high $p \mathrm{CO}_{2}$ mesocosms (M5, M6, M9); grey symbols: medium $p \mathrm{CO}_{2}$ mescosms (M1, M4, M8); blue symbols: low $p \mathrm{CO}_{2}$ mesocosms (M2, M3, M7).

\section{BGD}

9, 15541-15565, 2012

\section{Marine carbonate system evolution}

R. G. J. Bellerby et al.

Title Page

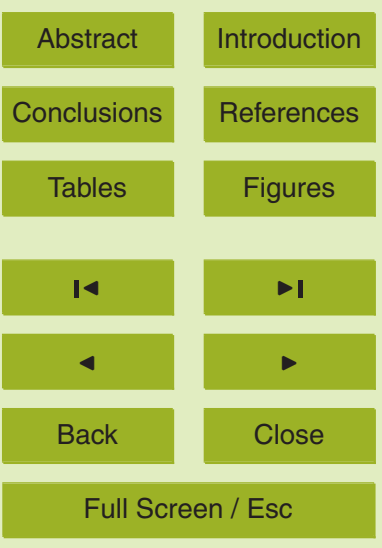

Printer-friendly Version

Interactive Discussion 

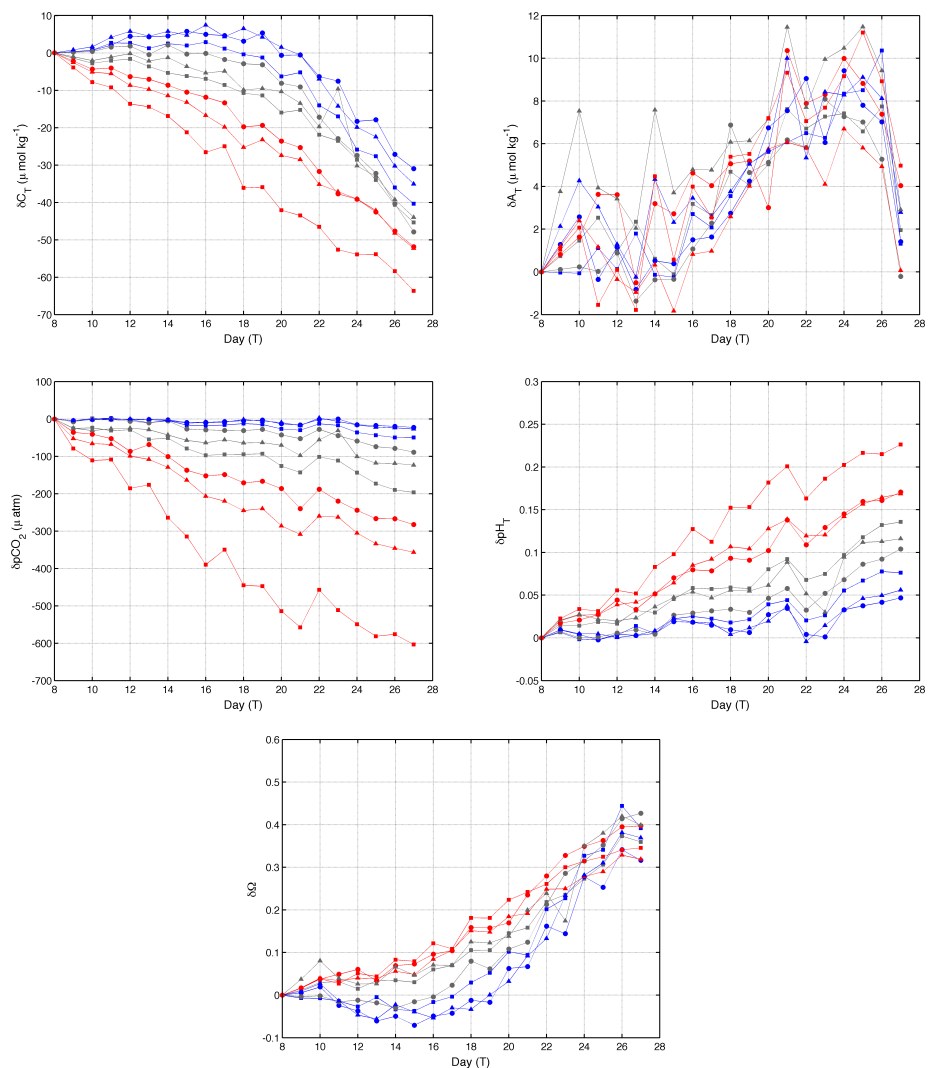

Fig. 5. Cumulative changes relative to the start of the post $\mathrm{CO}_{2}$ perturbtion (T-8). (a) total inorganic carbon $\left(C_{\mathrm{T}}\right)$, (b) total alkalinity $\left(A_{\mathrm{T}}\right)$, (c) partial pressure of carbon dioxide (pCO2), (d) $\mathrm{pH}_{\mathrm{T}}$ on the total hydrogen scale and (e) aragonite saturation state $\left(\Omega_{\mathrm{ar}}\right)$. Red symbols: high $p \mathrm{CO}_{2}$ mesocosms (M5, M6, M9), grey symbols: medium $p \mathrm{CO}_{2}$ mescosms (M1, M4, M8), blue symbols: low $p \mathrm{CO}_{2}$ mesocosms (M2, M3, M7).

\section{BGD}

9, 15541-15565, 2012

\section{Marine carbonate system evolution}

R. G. J. Bellerby et al.

Title Page

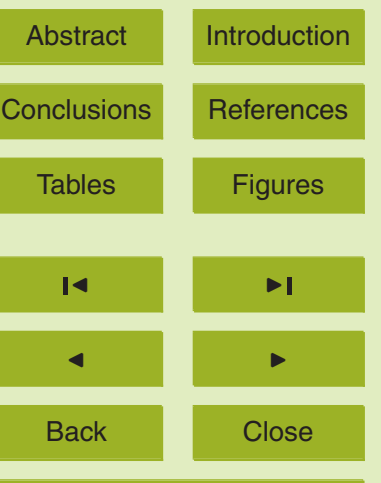

Full Screen / Esc

Printer-friendly Version

Interactive Discussion 
BGD

9, 15541-15565, 2012
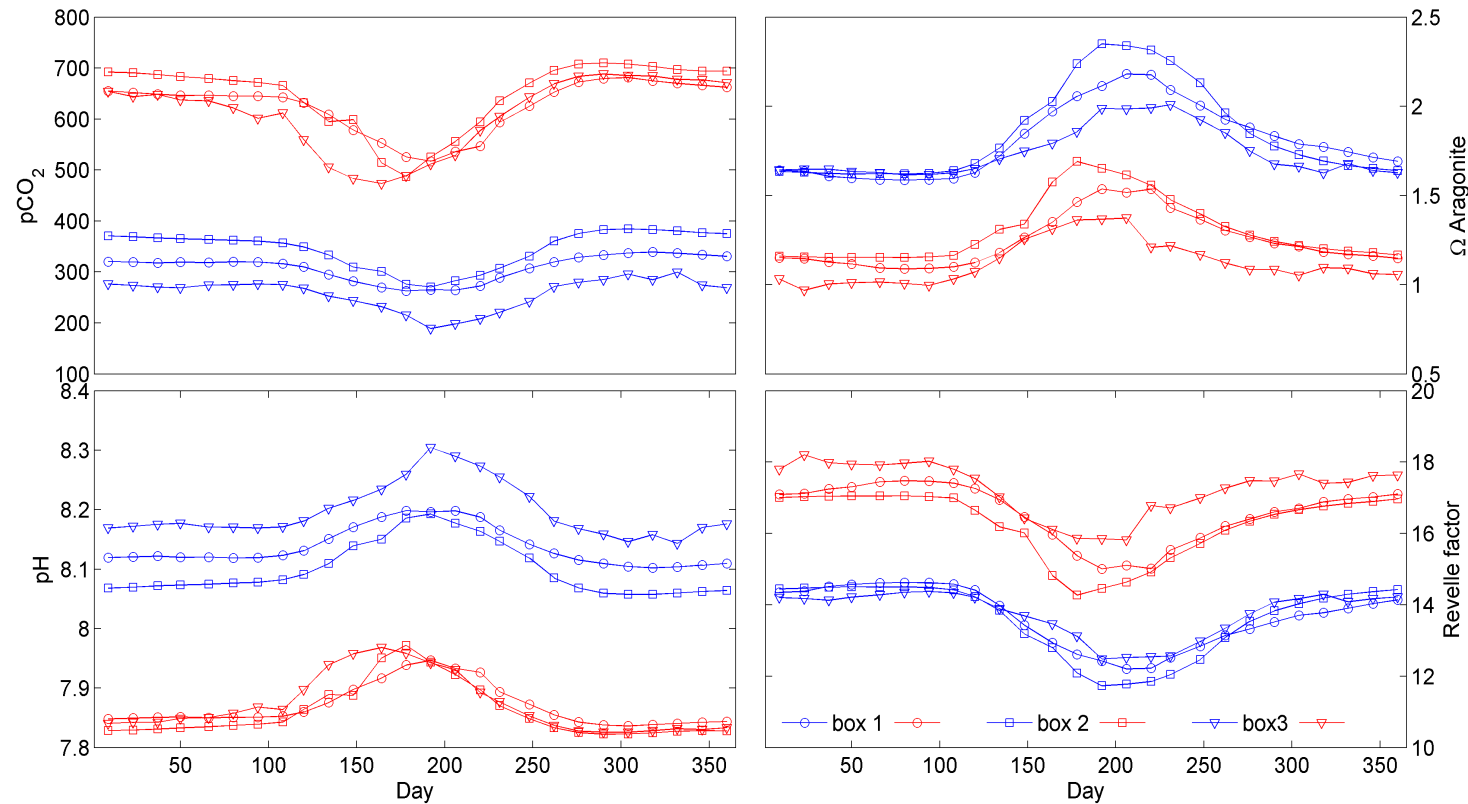

Fig. 6. Simulated mixed layer seasonal marine carbonate system dynamics for the regional sub-domains: $p \mathrm{CO}_{2}, \mathrm{pH}_{\mathrm{T}}$ and $\Omega_{\mathrm{ar}}$. The decadal means are shown as blue (period 2006-2015) and red (period 2090-2099) for the regions of the Barents Sea Opening (O); West Spitsbergen current $(\square)$ and the Arctic Shelf $(\nabla)$.

\section{Marine carbonate system evolution}

R. G. J. Bellerby et al.

Title Page

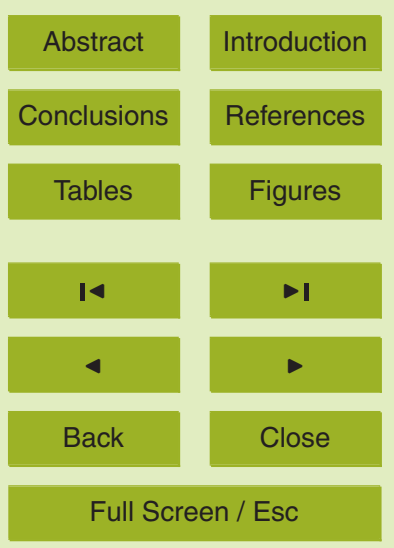

Printer-friendly Version

Interactive Discussion 


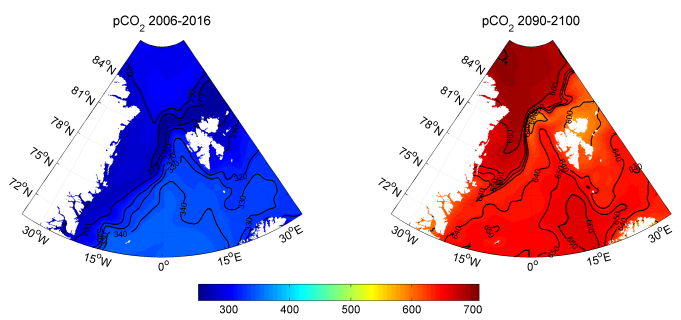

\section{BGD}

9, 15541-15565, 2012

\section{Marine carbonate system evolution}

R. G. J. Bellerby et al.

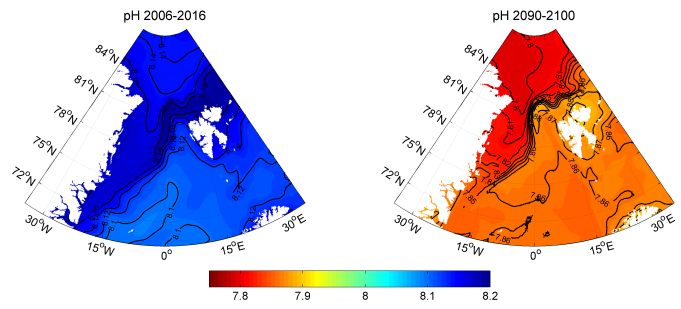

Title Page

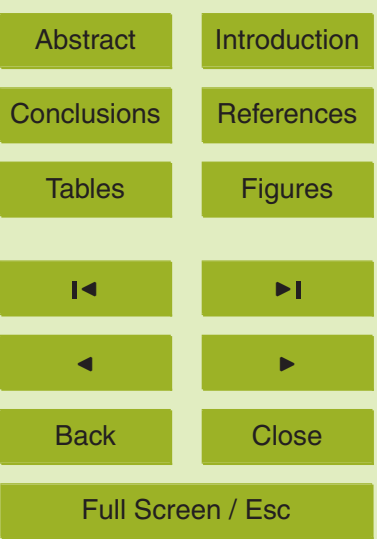

Printer-friendly Version

Fig. 7. Simulated mixed layer marine carbonate system values for the northern Nordic Seas and Eurasian Arctic Ocean. Decadal means are presented for the time-slices 2006-2015 and 2090-2099 for $p \mathrm{CO}_{2}, \mathrm{pH}_{\mathrm{T}}$ and $\Omega_{\mathrm{ar}}$.

Interactive Discussion 


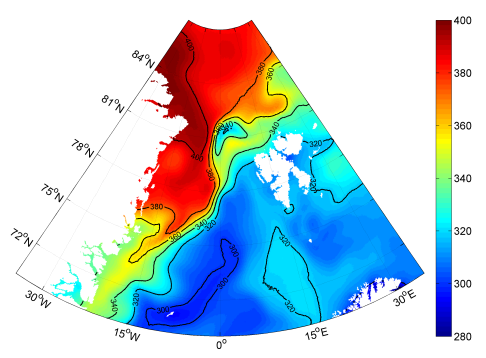

BGD

9, 15541-15565, 2012

\section{Marine carbonate system evolution}

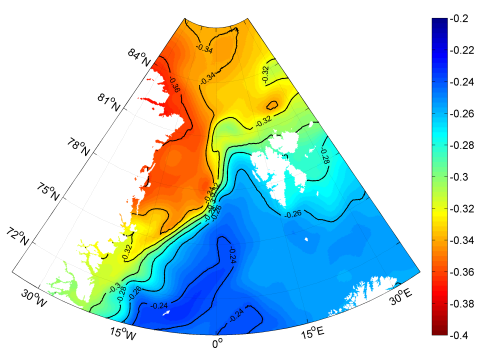

R. G. J. Bellerby et al.

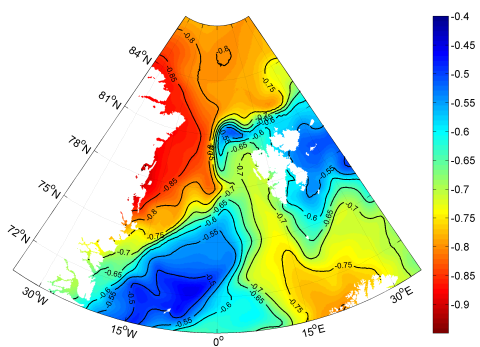

Title Page

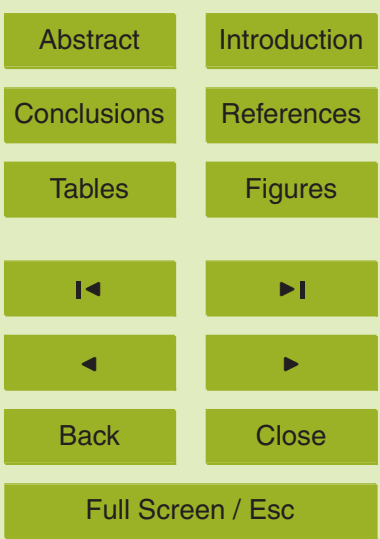

Printer-friendly Version

Fig. 8. Centennial changes in mixed layer marine carbonate system values for the northern Nordic Seas and Eurasian Arctic Ocean. The figures represent the difference between the decadal means in Fig. 6 for (a) $p \mathrm{CO}_{2}$; (b) $\mathrm{pH}_{\mathrm{T}}$ and (c) $\Omega_{\mathrm{ar}}$.

Interactive Discussion 